WARSZTATY Z GEOGRAFII TURYZMU

ISBN 978-83-7525-586-7 s. $141-147$

http://dx.doi.org/10.18778/7525-586-7.11

Michał MALARZ

Ujazd 98, 320-080 Zabierzów

\title{
ZMIANY W STRUKTURZE KANAŁÓW REZERWACJI USEUG HOTELOWYCH
}

Udział przemysłu turystycznego $\mathrm{w}$ polskim PKB wynosi 2\% (Marketingowa strategia... 2008). Źródłem około $45 \%$ korzyści z branży są hotele, a ich rola stale wzrasta (GAWORECKI 2007). Wzrost ruchu turystycznego wpływa na zwiększenie znaczenia i przemiany w organizacji pracy podmiotów rynku turystycznego. Dotyczy to także rezerwacji usług turystycznych, $\mathrm{w}$ tym usług hotelowych. Wraz z rozwojem technik łączności zmienia się struktura kanałów, przez które dokonuje się rezerwacji, co związane jest z dążeniem do lepszej organizacji oraz obniżenia kosztów.

W świetle przedstawionych przesłanek, przedmiotem niniejszej pracy jest zmiana struktury kanałów rezerwacji w hotelu. Celem autora jest określenie zmian struktury kanałów na tle postępu technologicznego w zakresie komunikacji. Opracowanie obejmuje zakres czasowy lat 1989-2009, a powstało $\mathrm{w}$ oparciu o materiały uzyskane $\mathrm{z}$ badań empirycznych przeprowadzonych w krakowskim hotelu Novotel „Bronowice”. Zawierają one informacje dotyczące kanałów rezerwacji oraz ich udziału w całkowitej liczbie rezerwacji.

Przyjęto założenie, że zmiana struktur kanałów dokonuje się pod wpływem nowych możliwości technicznych, które skutkują skróceniem czasu operacji, a także obniżeniem kosztów. Z punktu widzenia niniejszej pracy 
największe znaczenie ma określenie, w jaki sposób rozwój techniki komunikacyjnej wpłynął na zmianę struktury kanałów rezerwacji.

\section{Aspekt czasowy, ilościowy i jakościowy rezerwacji}

Novotel „Bronowice” jest obiektem działającym nieprzerwanie od roku 1974 (pod markami: Holiday Inn, Continental). Do dziś jest on własnością spółki Orbis i należy do systemu hotelowego Accor. Na lata 1989-2009 przypada pojawienie się nowych form wymiany informacji (fax, Internet) powszechnie używanych w obsłudze ruchu turystycznego. Dla celów analizy porównano dane $z$ lat 1989, 1999, 2009. W dekadzie 1989-1999 upowszechnił się fax, natomiast po roku 2000 na rynku pojawiły się OTA (On-line Travel Agent internetowe biuro podróży) będące nowymi podmiotami - pośrednikami usług turystycznych wykorzystującymi Internet.

Hotel dysponuje 304 pokojami, co plasuje go na drugim miejscu pod względem liczby pokoi na rynku krakowskim. Zdolność eksploatacyjna obiektu wynosi przeciętnie 9272 pokojonocy miesięcznie (110 960 na rok). W roku 2008 Novotel „Bronowice” odwiedziło 91000 gości¹. Około 30\% z nich to goście grupowi, a współczynnik podwójnej zajętości, czyli stosunek liczby gości zameldowanych do pokoi zajętych wynosi 1,5. Można zatem oszacować, iż do hotelu spłynęło około 42 tys. rezerwacji, które musiały zostać w odpowiedni sposób opracowane i przygotowane, tzn. wpisane do $\mathrm{PMS}^{2}$ oraz potwierdzone. Średnio jest to 116 rezerwacji dziennie.

Mówi się, że informacja jest krwiobiegiem gospodarki turystycznej, podkreślając tym samym jej kluczowy charakter (GAWORECKI 2007). Rezerwacja jest informacją o szczególnym znaczeniu. Czynnikiem decydującym o jej wartości ${ }^{3}$ jest jakość, wraz ze wszystkimi jej atrybutami. Relatywność, dokładność, aktualność, kompletność, spójność, odpowiednia prezentacja są konieczne dla pełnego wykorzystania danych (MAZUR 1970). Niska jakość danych może pociągać skutki finansowe, rozumiane jako utrata przychodów, ich zmniejszenie lub dodatkowe koszty dla przedsiębiorstwa. Precyzyjne dane $w$ tym zakresie są niezbędne do budowy modeli uzyskania optymalnych przychodów tzw. revenue management (JONES, HAMILTON 1992). W zarządzaniu rezerwacjami używane są systemy PMS zapewniające łatwy

\footnotetext{
${ }^{1}$ Dane z działu sprzedaży hotelu. Ta sama osoba nocująca wielokrotnie liczona oddzielnie.

2 Property Management System - np. Fidelio, Hogatex i inne dające kontrolę nad operacjami w hotelu.

${ }^{3}$ Wartość rozumiana dosłownie, możliwa do wyliczenia w konkretnych kwotach.
} 
dostęp i edycję danych. Zapisywane są w nich wszystkie rezerwacje wpływające do hotelu. Analiza odmów rezerwacji i tzw. no show (nazwa stosowana w przypadku, gdy gość nie pojawia się mimo rezerwacji) umożliwia z kolei wprowadzenie skutecznych praktyk overbookingu, czyli przyjmowania większej liczby rezerwacji niż liczba miejsc, którą hotel dysponuje, co jest obecnie powszechnie stosowane.

Rezerwacja stanowi też źródło danych. Dane i informacje tworzą fundament piramidy wiedzy. Przez hotelarzy używane są one nie tylko w celu zrealizowania zamówionej usługi. Są przedmiotem analizy dla działów marketingu oraz elementem sprawozdawczości dla Urzędu Statystycznego. Wśród gromadzonych danych wyróżnić należy: dane osobowe gościa, informacje kontaktowe, nazwę, adres, NIP płatnika, termin pobytu, szczegóły dotyczące typu pokoju.

\section{Charakterystyka i ocena efektywności kanałów rezerwacji}

Najogólniej kanały rezerwacji można podzielić na pośrednie i bezpośrednie.

Do kanałów bezpośrednich zalicza się:

- List. Zanim pojawił się fax i Internet, a telefony nie były popularne, stosowano listowną formę dokonywania rezerwacji usług. Ze względu na istnienie obecnie tańszych i szybszych alternatyw jest sporadycznie wykorzystywana. Obecnie list służy głównie do przesyłania oryginałów dokumentów, umów handlowych itd.

- Telefon. Kontakt telefoniczny umożliwia bezpośrednią rozmowę z przedstawicielem hotelu. Podczas rozmowy telefonicznej z klientem, oprócz treści rozmowy, ważna jest również jej forma.

- Fax. Wynalazek rodem z Japonii (gdzie nie funkcjonował telex) stał się bardzo popularnym medium do przesyłania dokumentów. Szeroko rozpowszechniony od $1985 \mathrm{r}$. Oferując przesyłanie dokumentów na odległość, zastąpił tradycyjną pocztę. Obecnie nie wytrzymuje konkurencji z Internetem. Zaletą faxu wciąż pozostaje możliwość przesyłania pisma odręcznego, w tym podpisów występujących często na różnego typu kontraktach.

- Walk-in. Szczególnym typem rezerwacji jest przypadek, gdy gość pojawia się $\mathrm{W}$ hotelu deklarując chęć skorzystania $\mathrm{z}$ noclegu bez wcześniejszego kontaktu.

- Strona internetowa hotelu. Zarówno małe, niezależnie działające obiekty, jak i funkcjonujące $\mathrm{w}$ systemie hotelowym posiadają swoje 
strony internetowe pozwalające na dokonanie rezerwacji, np. w oparciu o umieszczony na stronie formularz.

- E-mail. Z kanałem tym mamy do czynienia w przypadku przesłania rezerwacji na elektroniczną skrzynkę pocztową hotelu, bezpośrednio od klienta.

Do kanałów pośrednich zaliczamy wykorzystujące Internet portale, pozwalające na wyszukiwanie ofert $\mathrm{w}$ oparciu o indywidualne preferencje. Zaliczamy do nich:

- Strona pośrednika. W sieci funkcjonuje wiele firm - pośredników usług turystycznych, m.in. wspomniany już OTA. Tysiące ofert może być sortowanych według określonych kryteriów i preferencji.

- Globalne systemy rezerwacji (GDS) oraz systemy rezerwacji obsługujące sieci hotelowe (Holidex, TARS, inne) umożliwiają rezerwację usług turystycznych. Dostęp do tych systemów posiadają biura podróży, dając możliwość dokonania rezerwacji pojedynczych usług oraz imprez turystycznych.

Stopień doskonałości informacji jest zależny w dużym stopniu od czynnika ludzkiego. Nadawca, odbiorca oraz droga, jaką przebywa rezerwacja ma wpływ na jej jakość.

W przypadku przekazu telefonicznego występuje ryzyko związane $\mathrm{z}$ techniczną niedoskonałością samego połączenia, szumu informacyjnego otoczenia lub barierą językową. Aspekt ten jest przedmiotem ciągłych badań i udoskonalania4.

Rezerwacje otrzymywane faxem mogą być również niedoskonałe, gdyż pojawia się problem czytelności dokumentu, „efekt opóźnienia” wynikający $\mathrm{z}$ różnicy czasowej pomiędzy otrzymaniem dokumentu a jego przeczytaniem, a także ryzyko zaginięcia dokumentu, gdy z jednego urządzenia korzysta kilka osób/działów, co jest często spotykane.

Internet natomiast, oprócz dostarczenia informacji i pomocy w wyborze usługi, umożliwia łatwe przeprowadzenie transakcji, zamkniętej przedpłatą. Takich możliwości nie daje żaden inny kanał.

Istnieje kilka przyczyn używania sieci komputerowych do przesyłania informacji rezerwacyjnych, m.in.:

- przesyłanie danych jest tańsze niż obsługa rozmów,

- automatyczne potwierdzenia eliminują potrzebę manualnego potwierdzania rezerwacji,

- zostaje wyeliminowany błąd ludzki,

${ }^{4}$ Są stosowane badania typu mystery guest np. RESAVISION w systemie Accor. 
- można zawrzeć bardzo dokładne informacje dotyczące rezerwacji na potwierdzeniu.

Stosowanie technik informacyjnych ma jednak również poważne wady:

- może „odczłowieczać" charakter usługi hotelarskiej,

- może mieć negatywny wpływ na morale pracowników rezerwacji, którzy postrzegają nowoczesne technologie jako zagrożenie dla swoich stanowisk pracy (MEIDAN \& CHIU 1995).

Informacje dostępne w bazach programów hotelowych są często podstawą tworzenia programów typu Customer Relationship Management (CRM), czyli systemów zarządzania relacjami z klientem.

\section{Struktura kanałów rezerwacyjnych}

Przedstawiona na rys. 1 struktura kanałów rezerwacyjnych zawiera dane za lata 1989, 1999, 2009. Największe zmiany nastąpiły w dekadzie 1999-2009, kiedy przypada okres dynamicznego rozwoju technik informacji turystycznej w turystyce.

Bezpośrednie rezerwacje za pomocą poczty elektronicznej stanowiły w ro2009 około 6\% zbioru. Kanał ten nie występował jeszcze w roku 1989.

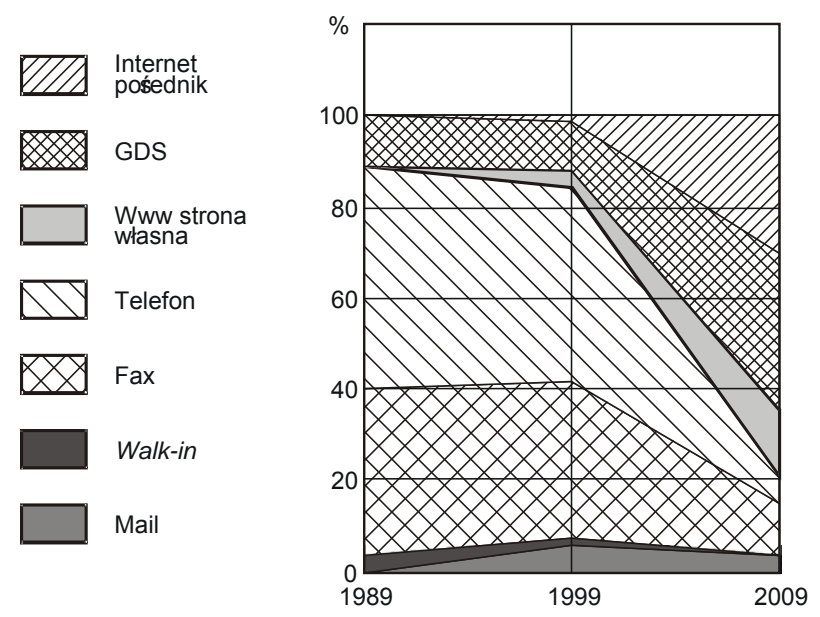

Rys. 1. Struktura kanałów rezerwacji w Novotelu „Bronowice” w Krakowie w roku 1989, 1999, 2009

Źródło: opracowanie własne na podstawie danych hotelu 
Na stałym, niskim poziomie 1\% kształtuje się liczba gości walk-in. Kanały te można zaliczyć do elementów stagnujących.

Kanał rezerwacji faxem można traktować jako element zanikający (do zanikłych zaliczyć można jego poprzednik - telex), a jego zmniejszające się znaczenie potwierdza 11-procentowy udział we wszystkich wykorzystywanych kanałach w 2009 r. (35\% w roku 1999). Zostaje on stopniowo wypierany przez kanały internetowe.

Strona własna hotelu, GDS oraz OTA to kanały w badanym okresie nowo pojawiające się. Charakteryzują się dużą dynamiką wzrostu i wspólnie reprezentowały w 2009 r. blisko 80\% wszystkich rezerwacji.

Telefon jest kanałem, przez który dociera aktualnie $6 \%$ rezerwacji. Należy wspomnieć, iż zainicjowana telefonicznie rezerwacja jest często finalizowana za pośrednictwem OTA lub GDS, co zafałszowuje statystyki ${ }^{5}$. W rzeczywistości pomimo rosnącej roli technik IT udział telefonu pozostaje znaczący. Należy wspomnieć tzw. efekt bilboardu, kiedy telefon i Internet traktowane są zamiennie jako źródło informacji i rzeczywisty kanał rezerwacji. Szacuje się, że w ten sposób rezerwuje nocleg 40\% klientów indywidualnych (ANDERSON 2009).

\section{Wnioski}

Występujące dawniej bariery związane z brakiem infrastruktury lub sprzętu niezbędnego do wymiany informacji nie są obecnie odnotowywane. Internetowe kanały rezerwacji stanowią obecnie $80 \%$ wszystkich rezerwacji. Charakter procedur rezerwacyjnych, ich monotonia i powtarzalność czynności związanych z obsługa, dają duże możliwości zastosowania metod technologii informacyjnej. Ich wykorzystanie powoduje podniesienie wydajności i obniżenie kosztów.

Turystyka jest gałęzią gospodarki, która musi przyswoić sobie zasady prowadzenia działalności gospodarczej z powszechnym stosowaniem technik informatycznych (NOWAKOWSKA 2004). Wiodące innowacyjne podmioty będą dążyć do wprowadzenia nowej organizacji pracy (SCHUMPETER 1960), a towarzyszące jej zmniejszenie kosztów będzie czynnikiem pobudzającym do zmian. Jednocześnie wystąpią czynniki hamujące. To brak wsparcia dla zmian ze strony pracowników obawiających się utraty pracy oraz przyzwy-

${ }^{5} \mathrm{~W}$ związku z dążeniem do maksymalizacji udziału rezerwacji gwarantowanych, co najłatwiej uzyskać korzystając z sieci. Fakt ten potwierdzają hotelarze.

146 | WARSZTATYZ GEOGRAFI TURYZMU 
czajenie części klientów do korzystania z telefonów, które umożliwiają bezpośrednią rozmowę z przedstawicielem hotelu.

Wzrastająca liczba podmiotów OTA na rynku oraz stosunkowo wysokie koszty niezbędnej infrastruktury technicznej podnoszą koszty rezerwacyjne $\mathrm{w}$ tym kanale. Mimo to, gdy z Internetu korzysta co czwarty mieszkaniec Ziemi, wiodące systemy OTA notują blisko $20 \mathrm{mln}$ odsłon miesięcznie (Expedia.com). Pokazuje to ogromny potencjał tej platformy. Sieć wciąż ewoluuje oferując nowe narzędzia programowe i stając się coraz bardziej przyjazna dla użytkownika.

\section{BIBLIOGRAFIA}

ANDERSON K., 2009, Revenue management for low-cost providers, „European Journal of Operational Research", vol. 188, No. 1, Ithaka.

GAWORECKI W., 2007, Turystyka, PWE, Warszawa.

JONES, P., HAmilton, D., 1992, Yield Management: Putting People in the Big Picture, "Cornell Hotel and Restaurant Administration Quarterly", No. 33 (February).

Marketingowa strategia Polski w sektorze turystyki na lata 2008-2015, 2008, POT, Warszawa.

MAZUR M., 1970, Jakościowa teoria informacji, WNT, Warszawa.

MEIDAN, CHIU, 1995, Hotel reservation methods - a discriminant analysis of practices in English hotels, Sheffield University Management School, Sheffield.

NOWAKOWSKA A., 2004, Ekonomiczne i organizacyjne aspekty rozwoju turystyki, WSIiZ, Rzeszów.

SCHUMPETER J., 1960, Teoria rozwoju gospodarczego, PWN, Warszawa. 